\title{
Hypothyroidism in the elderly: diagnosis and management
}

\author{
This article was published in the following Dove Press journal: \\ Clinical Interventions in Aging \\ 30 March 2012 \\ Number of times this article has been viewed
}

\author{
Isabela M Bensenor ${ }^{1,2}$ \\ Rodrigo D Olmos ${ }^{1,2}$ \\ Paulo A Lotufo ${ }^{1,2}$ \\ 'Division of Internal Medicine, \\ Hospital Universitário, University \\ of São Paulo, São Paulo, Brazil; \\ ${ }^{2}$ Department of Internal Medicine, \\ School of Medicine, University of São \\ Paulo, São Paulo, Brazil
}

\begin{abstract}
Thyroid disorders are highly prevalent, occurring most frequently in aging women. Thyroid-associated symptoms are very similar to symptoms of the aging process; thus, improved methods for diagnosing overt and subclinical hypothyroidism in elderly people are crucial. Thyrotropin measurement is considered to be the main test for detecting hypothyroidism. Combined evaluations of thyroid stimulating hormone (TSH) and free-thyroxine can detect overt hypothyroidism (high TSH with low free-thyroxine levels) and subclinical hypothyroidism (high TSH with normal free-thyroxine levels). It is difficult to confirm the diagnosis of thyroid diseases based only on symptoms, but presence of symptoms could be an indicator of who should be evaluated for thyroid function. The most important reasons to treat overt hypothyroidism are to relieve symptoms and avoid progression to myxedema. Overt hypothyroidism is classically treated using L-thyroxine; elderly patients require a low initial dose that is increased every 4 to 6 weeks until normalization of TSH levels. After stabilization, TSH levels are monitored yearly. There is no doubt about the indication for treatment of overt hypothyroidism, but indications for treatment of subclinical disease are controversial. Although treatment of subclinical hypothyroidism may result in lipid profile improvement, there is no evidence that this improvement is associated with decreased cardiovascular or all-cause mortality in elderly patients. In patients with a high risk of progression from subclinical to overt disease, close monitoring of thyroid function could be the best option.
\end{abstract}

Keywords: overt hypothyroidism, subclinical hypothyroidism, diagnosis, treatment, elderly

\section{Introduction}

Thyroid disorders are highly prevalent, most frequently afflicting aging women. ${ }^{1}$ It is crucial to advance the means of diagnosing thyroid diseases, especially overt and subclinical hypothyroidism in elderly people, because thyroid-associated symptoms are very similar to symptoms of the normal aging process. ${ }^{2,3}$

Up till the early 1980s, laboratory diagnosis of thyroid dysfunction was made using radioimmunoassay for thyroid stimulating hormone (TSH); however, this method did not detect decreased TSH values, and is not a good test for the diagnosis of hyperthyroidism. After the 1980s, immunometric assays for TSH emerged as the most cost-effective test for thyroid disease screening. ${ }^{4,5}$ The second-generation immunoassays can detect TSH values of $0.1 \mathrm{mIU} / \mathrm{L}$ and the third-generation assays are able to detect TSH values of $0.01 \mathrm{mIU} / \mathrm{L}$.

Thyroid gland hormone production is directly stimulated by TSH, which is synthesized and secreted in the anterior pituitary under stimulation of thyrotropin-releasing hormone produced in the hypothalamus. In patients with an intact
Correspondence: Isabela M Bensenor Hospital Universitário, Av Lineu Prestes 2565, $3^{\circ}$ andar, Centro de Pesquisa Clínica, CEP 05508-000, Brazil

Tel +55 I | 309| 9300

Fax +55 II 309| 924 I

Email isabensenor@hu.usp.br 
hypothalamic-pituitary-thyroid axis, a negative feedback regulatory mechanism controls thyroid gland metabolism. The pituitary serves as a biosensor of thyroid hormone levels and regulates TSH levels according to the feedback of free-thyroxine (FT4) and free-triiodothyronine (FT3) levels. Decreases in thyroid hormone production stimulate more TSH secretion. The control system has a relatively slow response time and during periods of non-equilibrium, as occurs in the beginning of hypothyroidism, it is possible to find some discordance between the plasma thyroid hormone concentrations and the levels of TSH.

TSH measurement is considered to be the main test for detecting thyroid disease, specifically overt and subclinical hypothyroidism, for three main reasons. Firstly, there is an inverse log-linear relationship between the concentrations of TSH and FT4. Consequently, small linear reductions in FT4 concentrations are associated with an exponential increase in TSH concentrations. Secondly, most cases of hypothyroidism in clinical practice are due to primary disease of the thyroid gland. Thirdly, immunometric assays for TSH present greater than $99 \%$ sensitivity and specificity. ${ }^{4,5}$

The second step in the screening of thyroid disorders is to determine the FT4 level. FT4 measurement is highly cost-effective compared to previously used measurements of total T4 or triiodothyronine. The combined measurements of TSH and FT4 can detect two types of hypothyroidism: overt and subclinical.

Overt hypothyroidism is defined as a combination of high TSH with low FT4, while subclinical hypothyroidism is defined as a combination of high TSH with normal FT4 levels. There is some controversy regarding the presentation of subclinical hypothyroidism; some guidelines define it as a situation in which the patient is asymptomatic, while others state that subclinical hypothyroidism might include a few symptoms, but without any specific information about what symptoms can be involved. ${ }^{5,6}$ Data from some studies have shown a positive relationship between increased TSH levels and the presence of antithyroid peroxidase antibodies. ${ }^{2,7}$ As subclinical hypothyroidism is defined by "high TSH with normal FT4," the exact normal range of TSH is very important. The TSH range must be assessed in people with no evidence of disease - without positive antibodies in the serum and with no alteration detected upon ultrasonographic examination. ${ }^{8}$ Another important point is that there is an individual hypothalamic-pituitary-thyroid axis set-point ${ }^{9}$ that is genetically determined; ${ }^{10}$ differences in the individual set-point could explain the spectra of different symptoms presented in subjects with similar TSH values. ${ }^{8}$
This is a selective review that primarily includes data about thyroid diseases in elderly men and women. However, several studies have included subjects aged 40 years or more and it is difficult to separate younger subjects from the older ones; therefore, some of the included data concern people of $\geq 40$ years old or at least a sample with a mean age $\geq 40$ years.

\section{Epidemiology of thyroid diseases}

Epidemiological studies have revealed that several changes in thyroid hormone concentrations occur with aging. The Whickham Survey undertaken in Britain provided data showing that TSH levels did not vary with age among males, but increased markedly among females after the age of 45 years. Furthermore, this rise in TSH with age among women was virtually abolished when persons with antithyroid antibodies were excluded from the sample. ${ }^{1}$ Data from the National Health and Nutrition Survey (NHANES III) confirmed that both TSH levels and the presence of antithyroid antibodies are greater in women, increase with age, and are more common in whites than in blacks. ${ }^{11}$

The Framingham study evaluated an unselected population of elderly subjects ( $>60$ years) and found a $4.4 \%$ prevalence of thyroid deficiency, as evidenced by a clearly elevated serum thyrotropin level greater than $10 \mu \mathrm{IU} / \mathrm{mL}$. Women exhibited thyroid deficiency $(5.9 \%)$ more often than men $(2.3 \%)$. The level of serum thyroxine (T4) was not a sensitive measure of thyroid deficiency. Of those with clearly elevated serum TSH levels, only $39 \%$ had low serum T4 levels; the remainder had serum T4 levels in the lower half of the normal range. An elevated serum TSH level has been noted as a sensitive marker of thyroid deficiency in the elderly, and is often the only way to detect it. ${ }^{12}$

More recently, data from several studies in healthy individuals without thyroid diseases have indicated that aging appears to be associated with decreased concentrations of TSH in healthy elderly humans, especially after inclusion of centenarians in the sample. ${ }^{13}$ This decrease could be attributed to an increased sensitivity to physiological negative feedback by thyroxin. ${ }^{14}$ The low serum concentrations of TSH result in clear, age-dependent declines in serum total and FT3 levels, whereas the reduction of both T4 secretion and peripheral T4 degradation of thyroxine results in no change in serum total and FT4 concentrations. ${ }^{14,15}$ In contrast, serum reverse-triiodothyronine, an inactivate metabolite of $\mathrm{T} 4$, seems to increase with age, especially in individuals with other chronic diseases. ${ }^{16}$ 
For a physician to correctly interpret a high TSH level in terms of a hypothyroidism diagnosis, the positive and negative predictive values must be known; these depend on the prevalence of the disease in the general population. As a general rule, higher hypothyroidism prevalence in a population sample indicates a higher positive predictive value of an increased TSH level for hypothyroidism diagnosis. So, in a population with a high prevalence of thyroid disease, the finding of an isolated increased TSH value should be sufficient to confirm the diagnosis.

A review published by the American College of Physicians in 1998 estimated that population studies showed a pooled prevalence of overt hypothyroidism of $2 \%$ in women $\geq 70$ years, and of $0.1 \%$ for men $\geq 60$ years. ${ }^{17,18}$ Table 1 shows the results of recent surveys for prevalence of overt and subclinical hypothyroidism in older subjects. We included only studies that used similar methodology high sensitive TSH and FT4 - to evaluate thyroid function. Most studies showed prevalence of between $1 \%$ to $10 \%$ of overt hypothyroidism, and of $1 \%$ to $15 \%$ of subclinical hypothyroidism, considering both genders. Frequencies of overt and subclinical hypothyroidism vary among the studies. Such variations could be associated with several local factors, including differences in iodine intake among populations, differences in cut-off values used for thyrotropin and FT4 levels and strategies of sample selection among studies.

Table 2 shows the results of two studies that evaluated the incidence of thyroid diseases in older people. Twenty years after the Whickham Survey, a follow-up of the cohort estimated the incidence and natural progression of thyroid disease. Of the 1877 surviving subjects, $91 \%$ were tested for clinical, biochemical, and immunological evidence of thyroid dysfunction. ${ }^{2}$ Among people with raised TSH levels alone at baseline, the odds ratio (OR) of having developed hypothyroidism at follow-up was eight (95\% Confidence Interval [CI], 3 to 20) for women and 44 (95\% CI, 19 to 104) for men. Among people with positive thyroid antibodies alone, the OR of having developed hypothyroidism at follow-up was eight ( $95 \%$ CI, 5 to 15 ) for women and 25 (95\% CI, 10 to 63 ) for men. The ORs among people with both conditions were 38 (95\% CI, 22 to 65) for women and 173 (95\% CI, 81 to 370 ) for men. In women, neither a positive family history nor parity showed an association with future development of hypothyroidism. ${ }^{2}$ Gopinath et al showed that the 5-year incidence of hypothyroidism in the older population was relatively low, and was associated with obesity (body mass index $\geq 30 \mathrm{~kg} / \mathrm{m}^{2}$ ) and serum TSH levels $>2 \mathrm{mIU} / \mathrm{L} .^{25}$

Table I Prevalence of overt and subclinical hypothyroidism in elderly people

\begin{tabular}{|c|c|c|c|c|c|}
\hline Reference & Place & Sample & Age of participants & Measurements $^{a}$ & Prevalence (\%) \\
\hline $\begin{array}{l}\text { Flatau et al }{ }^{19} \\
\text { cross-sectional }\end{array}$ & $\begin{array}{l}\text { Israel } \\
\text { Kibbutz members }\end{array}$ & $\begin{array}{l}75 \text { I ( } 289 \text { men } \\
\text { and } 462 \text { men) }\end{array}$ & $\begin{array}{l}\geq 65 \text { years } \\
\text { Range: } 65-92 \text { years }\end{array}$ & $\begin{array}{l}\text { TSH (>4.5 mlU/L), } \\
\text { FT4 (I } 4 \text { to } 28 \mathrm{pmol} / \mathrm{L})\end{array}$ & $\begin{array}{l}\text { Overt and subclinical } \\
\text { in men: } 9.7 \% \\
\text { Overt and subclinical } \\
\text { in women: } 18.2 \% \\
38 \% \text { of all hypothyroid } \\
\text { subjects presented } \\
\text { subclinical } \\
\text { hypothyroidism }\end{array}$ \\
\hline $\begin{array}{l}\text { Cappola et } a^{20} \\
\text { cohort study }\end{array}$ & $\begin{array}{l}\text { US, community } \\
\text { dwelling individuals }\end{array}$ & $\begin{array}{l}3233 \text { (1 } 307 \text { men } \\
\text { and I } 926 \text { women) }\end{array}$ & $\geq 65$ years & $\begin{array}{l}\text { TSH (>4.5 mlU/L), } \\
\text { FT4 (not informed) }\end{array}$ & $\begin{array}{l}\text { Overt: } 1.6 \% \\
\text { Subclinical: } 15.0 \%\end{array}$ \\
\hline $\begin{array}{l}\text { Gussekloo et } \text { al }^{21} \\
\text { cohort study }\end{array}$ & $\begin{array}{l}\text { The Netherlands, } \\
\text { population based }\end{array}$ & $\begin{array}{l}558 \text { (189 men } \\
\text { and } 369 \text { women) }\end{array}$ & $\geq 85$ years & $\begin{array}{l}\text { TSH }(>4.8 \mathrm{mIU} / \mathrm{L}) \\
\mathrm{FT} 4(<\mathrm{l} 3 \mathrm{pmol} / \mathrm{L})\end{array}$ & $\begin{array}{l}\text { Overt: } 7.0 \% \\
\text { Subclinical: } 5.0 \%\end{array}$ \\
\hline $\begin{array}{l}\text { Wilson et } \mathrm{al}^{22} \\
\text { cross-sectional }\end{array}$ & $\begin{array}{l}\text { United Kingdom, } \\
\text { community sample } \\
\text { registered with } \\
20 \text { family practices }\end{array}$ & $\begin{array}{l}5960 \text { (2892 men } \\
\text { and } 2980 \text { women) }\end{array}$ & $\geq 65$ years & $\begin{array}{l}\text { TSH (>5.5 mlU/L), } \\
\text { FT4 (<9 pmol/L), } \\
\text { FT3 (<3.5 pmol/L) }\end{array}$ & $\begin{array}{l}\text { Overt: } 0.4 \% \text { (men } 0.4 \% \\
\text { and women } 0.4 \% \text { ) } \\
\text { Subclinical: } 2.9 \% \text { (men } \\
2.0 \% \text { and women } 3.7 \% \text { ) }\end{array}$ \\
\hline Diaz-Olmos et $\mathrm{al}^{23}$ & $\begin{array}{l}\text { Brazil, women } \\
\text { at workplace }\end{array}$ & 314 & $\begin{array}{l}\geq 40 \text { years } \\
\text { Mean age: } 47.6 \text { years }\end{array}$ & $\begin{array}{l}\text { TSH ( }>4.0 \mathrm{mlU} / \mathrm{L}) \\
\mathrm{FT} 4 \text { ( }<10 \mathrm{pmol} / \mathrm{L})\end{array}$ & $\begin{array}{l}\text { Overt: } 3.5 \% \\
\text { Subclinical: } 7.3 \%\end{array}$ \\
\hline $\begin{array}{l}\text { Bensenor et al }{ }^{24} \\
\text { cross-sectional }\end{array}$ & $\begin{array}{l}\text { Brazil } \\
\text { population-based }\end{array}$ & $\begin{array}{l}\text { I } 373 \text { (538 men } \\
\text { and } 835 \text { women) }\end{array}$ & $\geq 65$ years-old & $\begin{array}{l}\mathrm{TSH}(>5.0 \mathrm{mIU} / \mathrm{L}) \\
\mathrm{FT} 4(<10 \mathrm{pmol} / \mathrm{L})\end{array}$ & $\begin{array}{l}\text { Overt } \\
\text { Men: } 5.4 \% \\
\text { Women: } 5.9 \% \\
\text { Subclinical } \\
\text { Men: } 6.1 \% \\
\text { Women: } 6.7 \%\end{array}$ \\
\hline
\end{tabular}

Abbreviations: TSH, thyrotropin or thyroid stimulating hormone; FT4, free-thyroxine; FT3, free-triiodothyronine. Note: ${ }^{a}$ Measurements (cut-off points for diagnosis of overt hypothyroidism). 
Table 2 Incidence of overt hypothyroidism in elderly people

\begin{tabular}{|c|c|c|c|c|c|}
\hline Reference & Place & Sample & Age of participants & Measurements $^{a}$ & Incidence (\%) \\
\hline $\begin{array}{l}\text { Vanderpump et al } \mathrm{a}^{2, \mathrm{~b}} \\
\text { cohort study }\end{array}$ & United Kingdom & $\begin{array}{l}\text { I877, population } \\
\text { based }\end{array}$ & $\geq 38$ years & $\begin{array}{l}\text { TSH (not informed), } \\
\text { FT4 (not informed) }\end{array}$ & $\begin{array}{l}\text { Overt } \\
\text { Men: } 0.6 / 1000 \text { survivors/year } \\
\text { Women: } 3.5 / 1000 \text { survivors/year }\end{array}$ \\
\hline $\begin{array}{l}\text { Gopinath et al }{ }^{25} \\
\text { cohort study }\end{array}$ & Australia & $\begin{array}{l}951 \text {, population } \\
\text { based }\end{array}$ & $\geq 55$ years & $\begin{array}{l}\mathrm{TSH}(>4.0 \mathrm{mIU} / \mathrm{L}) \\
\mathrm{FT} 4(<\mathrm{II} .5 \mathrm{pmol} / \mathrm{L})\end{array}$ & $\begin{array}{l}\text { Overt } \\
\text { Men: } 1.4 \% / 5 \text { year } \\
\text { Women: } 3.5 \% / 5 \text { year } \\
\text { Subclinical } \\
\text { Men: } 0.7 \% / 5 \text { year } \\
\text { Women: } 2.5 \% / 5 \text { year }\end{array}$ \\
\hline
\end{tabular}

Notes: a Measurements (cut-off for diagnosis of overt hypothyroidism); bas there are few studies evaluating incidence of overt hypothyroidism in elderly people, this study was included; mean age was 58 years (range 38-93 years).

Abbreviations: TSH, thyrotropin or thyroid stimulating hormone; FT4, free-thyroxine.

\section{Diagnosis of hypothyroidism in elderly people}

Diagnosis of hypothyroidism is not easy because most of the symptoms, especially in mild cases, are nonspecific and are frequently attributed to other causes or to the aging process itself. This is especially a problem in older patients because symptoms such as fatigue, lack of concentration, dry skin, and many others are considered - correctly or not - to be normal parts of the aging process. Three different clinical conditions - hypothyroidism, depression, and presence of anemia - share common and nonspecific symptoms and are each common conditions in older people. The frequency of anemia, defined according to the World Health Organization, is higher than $10 \%$ in community-dwelling adults aged 65 years and older, and is frequently associated with other clinical conditions. ${ }^{26,27}$ Depressive symptoms, or even depression, are common in elderly people, especially associated with other physical comorbidities. ${ }^{28,29}$ Within this setting, the differential diagnosis of these three conditions is crucial.

It is impossible to confirm a diagnosis of hypothyroidism based on clinical symptoms alone, without TSH and FT4 determinations. Due to the increased prevalence according to age and the impossibility of ruling out the diagnosis without laboratory measurements, several guidelines recommend routinely screening for thyroid diseases after a certain age. ${ }^{30}$ The American Thyroid Association recommends screening both women and men at 35 years of age, and every 5 years thereafter. ${ }^{31}$ Also assertively in favor of screening, The American Association of Clinical Endocrinologists recommends screening in older patients, especially for women, ${ }^{32}$ and the American College of Pathologists recommends evaluations for women aged over 50 years with one or more general symptoms that could be caused by thyroid disease. ${ }^{33}$ The American Academy of Family Physicians recommends screening for patients over 60 years old, independent of gender, ${ }^{34}$ and the American College of Physicians recommends high-risk strategy for people aged over 50 years with nonspecific complaints. ${ }^{17,18}$ Among organizations that encourage screening, there is no agreement regarding the guidelines for age and sex.

In contrast, other institutions such as the US Preventive Services Task Force, ${ }^{35}$ the Canadian Task Force on the Periodic Health Examination, ${ }^{36}$ and the British Royal College of Physicians ${ }^{37}$ do not recommend screening for adults or for the elderly. The Institute of Medicine evaluated evidence for a benefit of screening for thyroid disorders in the Medicare population, but decided against screening based on a cost-effectiveness analysis. ${ }^{38}$ In 2004, an independent panel sponsored by three major professional societies - the American Thyroid Association, the American Association of Clinical Endocrinologists, and the Endocrine Society - recommended against screening $;{ }^{39}$ however, the three sponsoring societies did not endorse a statement in favor of screening.

Table 3 shows the results of studies that evaluated the diagnosis of unrecognized hypothyroidism in elderly people in different scenarios. The frequency of overt thyroid diseases without previous diagnosis is low, around $1 \%$ in men and $2 \%$ in women. In many cases, symptoms of hypothyroidism are insidious and may go unnoticed for months or even years, making medical diagnosis difficult. ${ }^{44}$ It is important to note that the diagnosis of overt thyroid disease now occurs earlier in the disease progression, so the comprehensive list of symptoms described in internal medicine books is almost never fully present. The only study that evaluated unrecognized hypothyroidism diagnosis in an emergency department found a very small number of cases. ${ }^{43}$ However, it was a retrospective study using data from hospital admissions, with the typical limitations of this type of strategy. 
Table 3 Unrecognized cases of overt hypothyroidism in elderly people at different scenarios

\begin{tabular}{|c|c|c|c|c|c|}
\hline Reference & Place & Sample & Age of participants & Measurements & $\begin{array}{l}\text { Frequency of unrecognized cases } \\
\text { of overt hypothyroidism (\%) }\end{array}$ \\
\hline \multicolumn{6}{|l|}{ Primary care } \\
\hline $\begin{array}{l}\text { Petersen et al }{ }^{40} \\
\text { cross-sectional }\end{array}$ & Sweden & II54, population based & $\geq 50$ years & TSH, FT4 & Women: $1.3 \%$ \\
\hline $\begin{array}{l}\text { Bemben et al } \\
(\text { Part I })^{4 I} \\
\text { retrospective }\end{array}$ & US & $\begin{array}{l}283 \text {, retrospective analysis } \\
\text { in a Department of Family } \\
\text { Medicine }\end{array}$ & $\begin{array}{l}>60 \text { years } \\
\text { Range: } 60-97 \text { years }\end{array}$ & TSH, FT4 & $\begin{array}{l}\text { Men: } 1.3 \% \\
\text { Women: } 1.0 \%\end{array}$ \\
\hline $\begin{array}{l}\text { Bensenor et al }{ }^{24} \\
\text { cross-sectional }\end{array}$ & Brazil & 1373, population based & $\geq 65$ years & TSH, FT4 & $\begin{array}{l}\text { Men: } 4.8 \% \\
\text { Women: } 3.4 \%\end{array}$ \\
\hline \multicolumn{6}{|c|}{ Outpatient clinics } \\
\hline $\begin{array}{l}\text { Nyström et al }{ }^{42} \\
\text { cross-sectional } \\
\text { Ward }\end{array}$ & Sweden & $\begin{array}{l}496, \text { users of an } \\
\text { outpatient clinic }\end{array}$ & $\geq 50$ years & TSH, FT4 & Women: $2.2 \%$ \\
\hline $\begin{array}{l}\text { Nyström et al }{ }^{42} \\
\text { cross-sectional }\end{array}$ & Sweden & $\begin{array}{l}\text { 383, inpatients of } \\
\text { emergency ward }\end{array}$ & $\geq 50$ years & TSH, FT4 & Women: I.3\% \\
\hline \multicolumn{6}{|c|}{ Emergency department } \\
\hline $\begin{array}{l}\text { Chen et al }{ }^{43, \mathrm{a}} \\
\text { retrospective }\end{array}$ & Taiwan & $\begin{array}{l}54,756 \text {, hospital admissions } \\
\text { at emergency department }\end{array}$ & $\begin{array}{l}\text { Mean age: } \\
75.8 \pm 12.8 \\
\text { Range: } \\
27-98 \text { years }\end{array}$ & TSH, FT4 & $\begin{array}{l}\text { Overt: } 0.1 \% \text { (men } 0.06 \% \text {, women: } 0.04 \% \text { ) } \\
\text { Myxedema: } 0.01 \% \\
\text { Only } 21 \% \text { of patients were admitted } \\
\text { from the emergency room with an } \\
\text { initial impression of primary overt } \\
\text { hypothyroidism }\end{array}$ \\
\hline
\end{tabular}

Note: a As there are no studies evaluating unrecognized cases of overt hypothyroidism in emergency department only in samples of elderly people, this study (age range $27-98$ years) was included; however mean age of subjects was $75.8 \pm 12.8$ years.

Abbreviations: TSH, thyrotropin or thyroid stimulating hormone; FT4, free-thyroxine.

Table 4 lists the most recent studies that have addressed the presence of symptoms in subjects with subclinical hypothyroidism compared to controls. Most of these studies did not show differences in the presence of clinical symptoms, anxiety and depressive symptoms, or worse cognitive performance in subjects with subclinical hypothyroidism compared to controls with normal thyroid function in different scenarios. Although it is not often possible to confirm the diagnosis of thyroid diseases based only on symptoms, the presence of symptoms could be an indicator of who should be screened for thyroid function. ${ }^{51}$

Canaris et al evaluated the use of a positive likelihood ratio (LR) associated with several symptoms to identify hypothyroidism. ${ }^{44}$ They applied a questionnaire, asking about 14 symptoms associated with hypothyroidism, in patients with and without overt hypothyroidism who were selected from the laboratory according to their levels of TSH and FT4. They also asked the patients to report if each of the symptoms had changed in the last year. Euthyroid subjects reported a mean of $16.5 \%$ and hypothyroid subjects reported $30.2 \%$ of listed symptoms $(P<0.0001)$. Symptoms that occurred more frequently in cases than controls were hoarse voice $(17 \%$ versus $4 \%$; positive LR, 4.2 ; $95 \%$ CI, 1.7-10.6), dry skin (71\% versus $54 \%$; positive LR, 1.3 ; 95\% CI, 1.1-1.6), and muscle cramps ( $34 \%$ versus $15 \%$; positive LR, $2.2 ; 95 \% \mathrm{CI}$,
1.4-3.7). When asked if the symptoms had changed in the last year, increased frequency of symptoms was reported more often in hypothyroid subjects compared to controls, with 13 symptoms presenting statistically significant differences: hoarse voice, deeper voice, drier skin, colder, more tired, puffier eyes, more muscle cramps, weaker muscles, more constipated, more depressed, slower thinking, poorer memory, and more difficulty with math. For diagnosing hypothyroidism, the LR was 0.5 for no reported symptoms compared to an LR of 8.7 (95\% CI, 3.8-20.2) for the presence of seven or more symptoms. ${ }^{44}$ Using data from the literature to determine a pretest probability of hypothyroidism according to age and sex, this knowledge of the LR enables calculation of the post-test probability using the nomogram of Fagan, and to consequently "rule in" or "rule out" the diagnosis of hypothyroidism. ${ }^{52}$

\section{Treatment of overt hypothyroidism}

The most important reasons to treat overt hypothyroidism are the relief of symptoms and to avoid progression of disease to myxedema. In elderly people, low levels of $\mathrm{TSH}^{53}$ or high levels of FT4 that are still in the normal range are associated with higher mortality, ${ }^{3}$ but the same is not clear for high levels of $\mathrm{TSH}^{21}$ or low levels of FT4. ${ }^{3}$ Gussekloo et al evaluated a general population of people who were 85 years of age at 


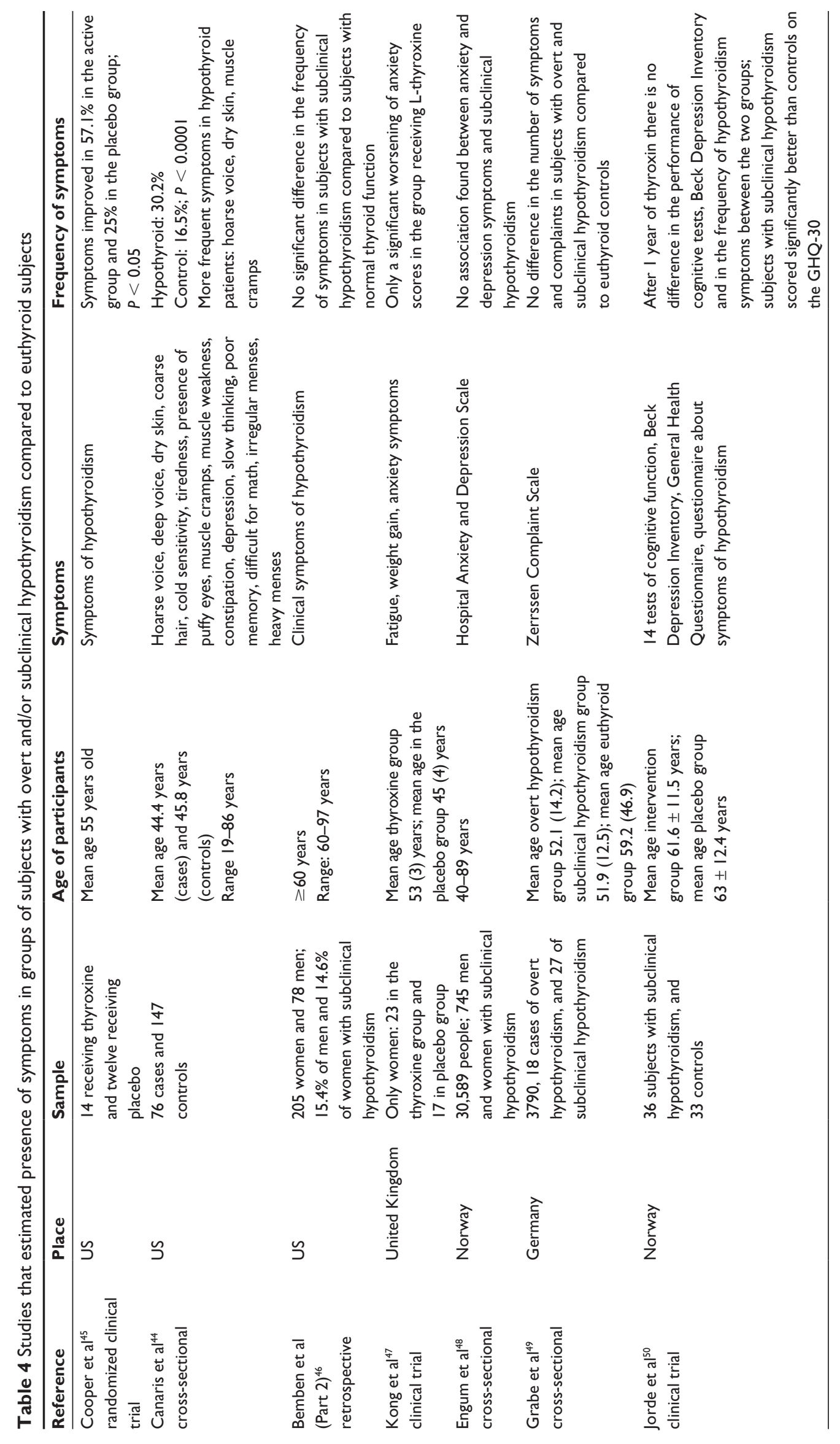


the beginning of the study, ${ }^{21}$ after a follow-up of 4 years, they concluded that elderly individuals with high TSH levels have a prolonged life span. The hazard ratio for mortality was 0.77 (95\% CI, 0.63 to 0.94 ) for a standard deviation increase of $2.71 \mathrm{mIU} / \mathrm{L}$ of thyrotropin. Likewise, van den Beld et al showed that low serum FT4 levels are associated with a longer 4-year survival, reflecting a possible adaptive mechanism to prevent excessive catabolism in the elderly. ${ }^{3}$

Overt hypothyroidism is classically treated by oral replacement with synthetic L-thyroxine. L-thyroxine is peripherally converted to FT3, the active form of thyroid hormone; it has a half-life of 6 days and is typically administered as a once-daily dose of $1.6 \mu \mathrm{g} / \mathrm{kg} .{ }^{54}$ Although, some authors recommend to use an initial dose lower than the usual dose to treat overt hypothyroidism in elderly patients, ${ }^{8,54}$ there is little evidence about this issue. A small study suggested that elderly patients need a lower dose of L-thyroxine compared to younger patients. ${ }^{55}$ Contrasting, a recent clinical trial concluded that a full starting dose of levothyroxine in asymptomatic patients (mean-age of 47 years, range of 25-86 years) is safe and may be more convenient and cost-effective than a low starting dose regimen. No patients were excluded from the analysis based on the presence of side effects of L-thyroxine. However, patients with previous history of coronary heart disease were excluded from the samples and most of them were elderly. ${ }^{56} \mathrm{~A}$ retrospective study evaluated L-thyroxine replacement doses and found no differences between younger and older patients regarding the L-thyroxine doses used. ${ }^{57}$ After stabilization, TSH levels can be monitored yearly. The most frequent complications of treatment in older people are myocardial ischemia and arrhythmias, especially atrial fibrillation, although these still occur at a low rate. ${ }^{8,13,58}$

Some researchers have evaluated whether a combination of T4 and triiodothyronine or even liothyronine could provide better treatment for patients with persistent symptoms following treatment with L-thyroxine alone. Liothyronine is another form of thyroid hormone; it reaches peak concentrations at 2-4 hours after oral administration with a half-life of 1 day, and thus cannot be used as a once-daily dose. ${ }^{59}$ Combined treatment using L-thyroxine and triiodothyronine produced some positive results related to cognition and sensation of well-being in small trials, ${ }^{60,61}$ but most results showed no improvement with combined treatment. ${ }^{62-64}$ Clyde et al tested a combination of levothyroxine plus liothyronine in the treatment of overt hypothyroidism and showed no beneficial changes in body weight, serum lipid levels, hypothyroid symptoms, or standard measures of cognitive performance from the combination treatment compared to L-thyroxine alone. ${ }^{59}$ Walsh et al also evaluated a combined thyroxine/liothyronine therapy with similar results. $^{65}$

In a double-blind, placebo-controlled, crossover trial of L-thyroxine, Pollock et al evaluated the effect of treatment in people who exhibited symptoms of hypothyroidism but had thyroid function tests within the reference range. The same protocol was used for patients and controls. ${ }^{66}$ L-thyroxine was no more effective than placebo in improving cognitive function or psychological well-being in patients or controls. ${ }^{66}$

\section{Treatment of subclinical hypothyroidism}

The most important reasons to treat subclinical hypothyroidism are to relieve symptoms, to avoid progression to overt disease, and to possibly prevent cardiovascular and all-cause mortality that may be associated with subclinical disease. Most patients diagnosed as having subclinical hypothyroidism have a low risk of complications and it is possible that their being labeled as having a "disease" is more dangerous than the actual risk of possible problems.

Table 5 shows the results of several clinical trials that have evaluated the effects of L-thyroxine administration in elderly people with subclinical hypothyroidism. Most of these studies were performed in subjects aged $\geq 50$ years, or at least with a great part of the sample being $\geq 45$ years old. Several trials did not show improvement of clinical symptoms of hypothyroidism, ${ }^{45,67-69,76}$ while only one trial showed improvement in tiredness after treatment with L-thyroxine. ${ }^{72}$ However, several trials showed some kind of improvement in cardiovascular risk factors related to lipid profile. ${ }^{69,71-74}$ One trial that evaluated C-reactive protein did not find any improvement after treatment with L-thyroxine. ${ }^{70}$ Another trial verified an improvement in pulse-wave velocity after treatment with L-thyroxine. ${ }^{75}$

A second reason to treat subclinical hypothyroidism is to avoid progression to overt disease. The two most important characteristics suggesting a progression of subclinical hypothyroidism to overt disease are high TSH levels, especially when $>10 \mathrm{IU} / \mathrm{L}$, and the presence of antithyroid peroxidase antibodies. Both measurements can be followed by periodic testing every year or every 6 months. Table 6 shows two studies that evaluated the risk of developing overt hypothyroidism in subjects who had baseline levels of high TSH, antithyroid antibodies, or both. The combination of high TSH with antithyroid peroxidase antibodies was associated with 

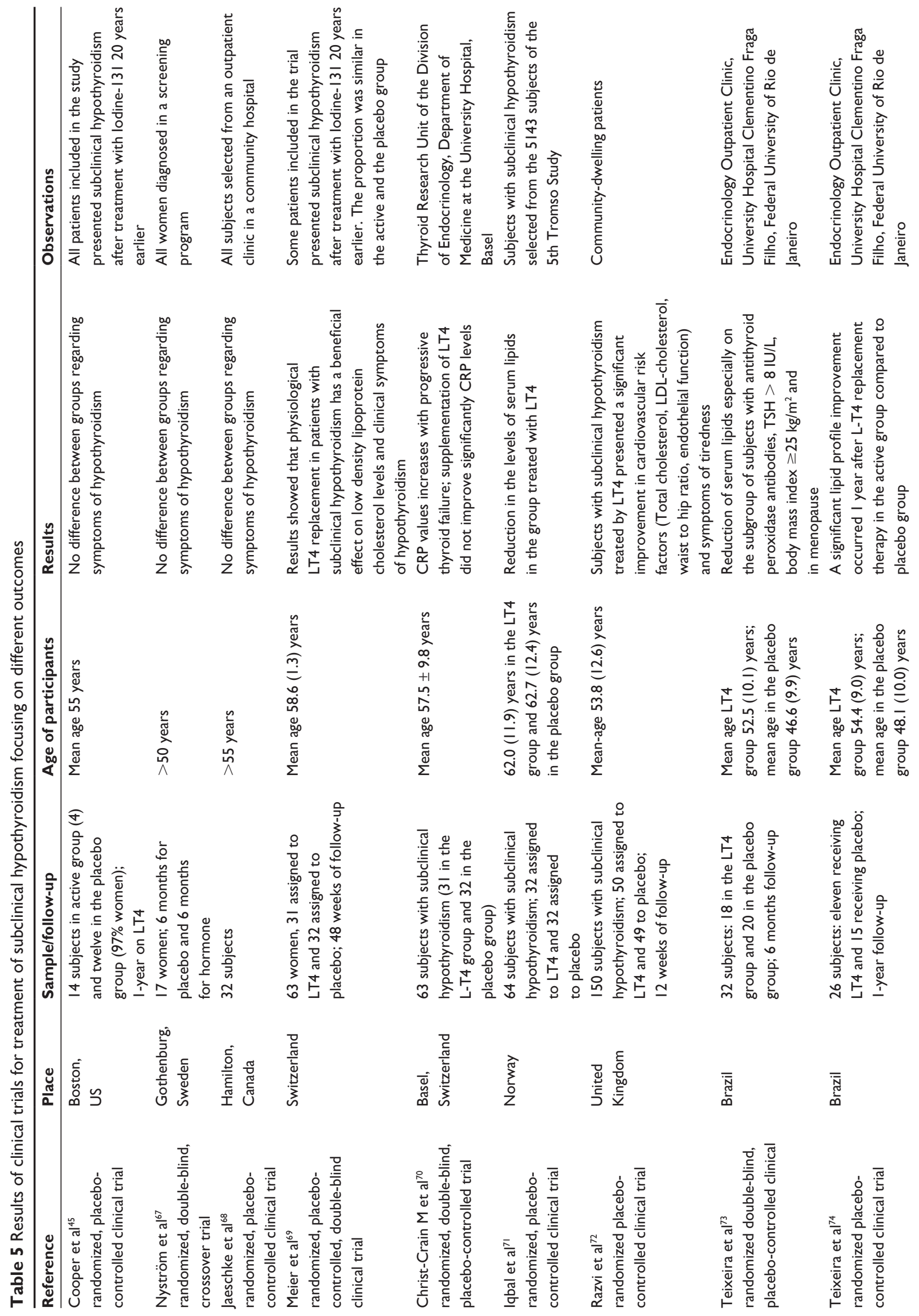

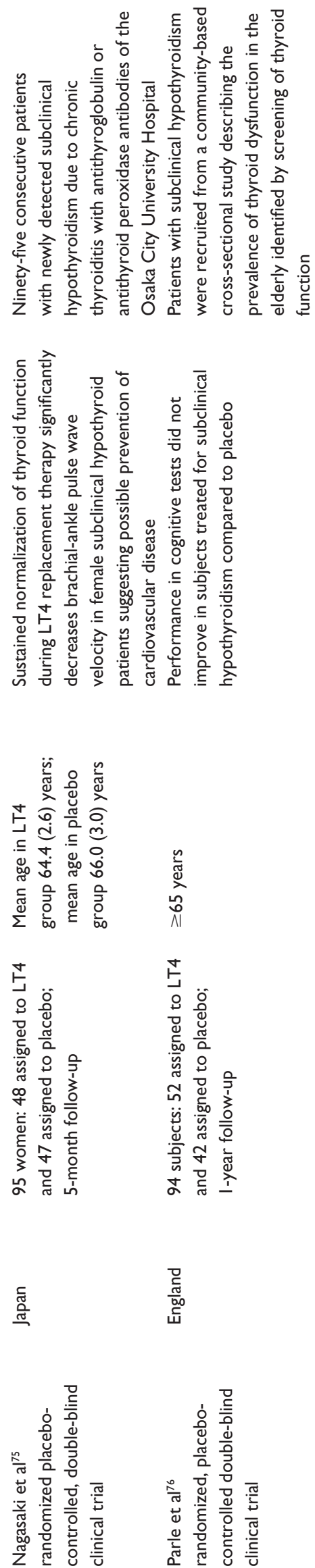

a high increase in the risk of developing overt disease. ${ }^{2,76} \mathrm{In}$ a prospective 5-year analysis of a cohort study, Gopinath et al evaluated the prognostic risk factors at baseline associated with forthcoming subclinical or overt hypothyroidism. Female sex and high TSH as continuous variables were associated with increased risk of subclinical hypothyroidism. Fasting blood glucose, total white cell count (as a continuous variable), and obesity (body mass index $\geq 30 \mathrm{~kg} / \mathrm{m}^{2}$ ) were associated with increased risk of progression to overt disease. ${ }^{25}$ Although progression to overt disease is higher in the presence of these risk factors, it is possible to closely monitor the progression of subclinical hypothyroidism to overt disease.

As subclinical hypothyroidism has been associated with a worse profile of cardiovascular risk factors such as lipid alterations, one possible complication of not treating subclinical hypothyroidism could be an increased cardiovascular risk. Another possible risk is if hypothyroidism is associated with an increased all-cause mortality mediated by some unknown factors beyond the causal pathway of dyslipidemia-heart disease.

Table 7 shows a list of cohort studies that estimated the incidences of cardiovascular disease or fractures in subjects with subclinical hypothyroidism. Only one study found an increased risk of congestive heart failure of $2.58(95 \% \mathrm{CI}$, 1.19-5.60) in subjects with TSH between $7.0 \mathrm{mIU} / \mathrm{L}$ to $9.9 \mathrm{mIU} / \mathrm{L}$, and of 3.26 (95\% CI, 1.37-7.77) in subjects with $\mathrm{TSH} \geq 10.0 \mathrm{mIU} / \mathrm{L} .{ }^{78}$ Another showed an increased risk of hip fracture, only in men, with a multivariable-adjusted hazard ratio of 2.31 (95\% CI, 1.25-4.27) ${ }^{83}$ Regarding mortality, only one study found an increased risk of all-cause mortality; ${ }^{80}$ another showed a higher risk of cardiovascular mortality associated with subclinical hypothyroidism. ${ }^{80}$ So, although subclinical hypothyroidism is associated with a higher frequency of cardiovascular risk factors, most evidence indicates that the effect is not sufficient to increase cardiovascular mortality or all-cause mortality. There is insufficient evidence that treatment of subclinical hypothyroidism could be associated with a decrease in all-cause or cardiovascular mortality in the elderly.

This was reinforced by the results of a meta-analysis that analyzed the influence of age on the relationship between subclinical hypothyroidism and ischemic heart disease. It included 15 studies with 2531 participants with subclinical hypothyroidism and 26,491 euthyroid individuals. Incidence and prevalence of ischemic heart disease were higher in subjects aged $<65$ years with subclinical hypothyroidism, but not in studies that included subjects aged $>65$ years. 


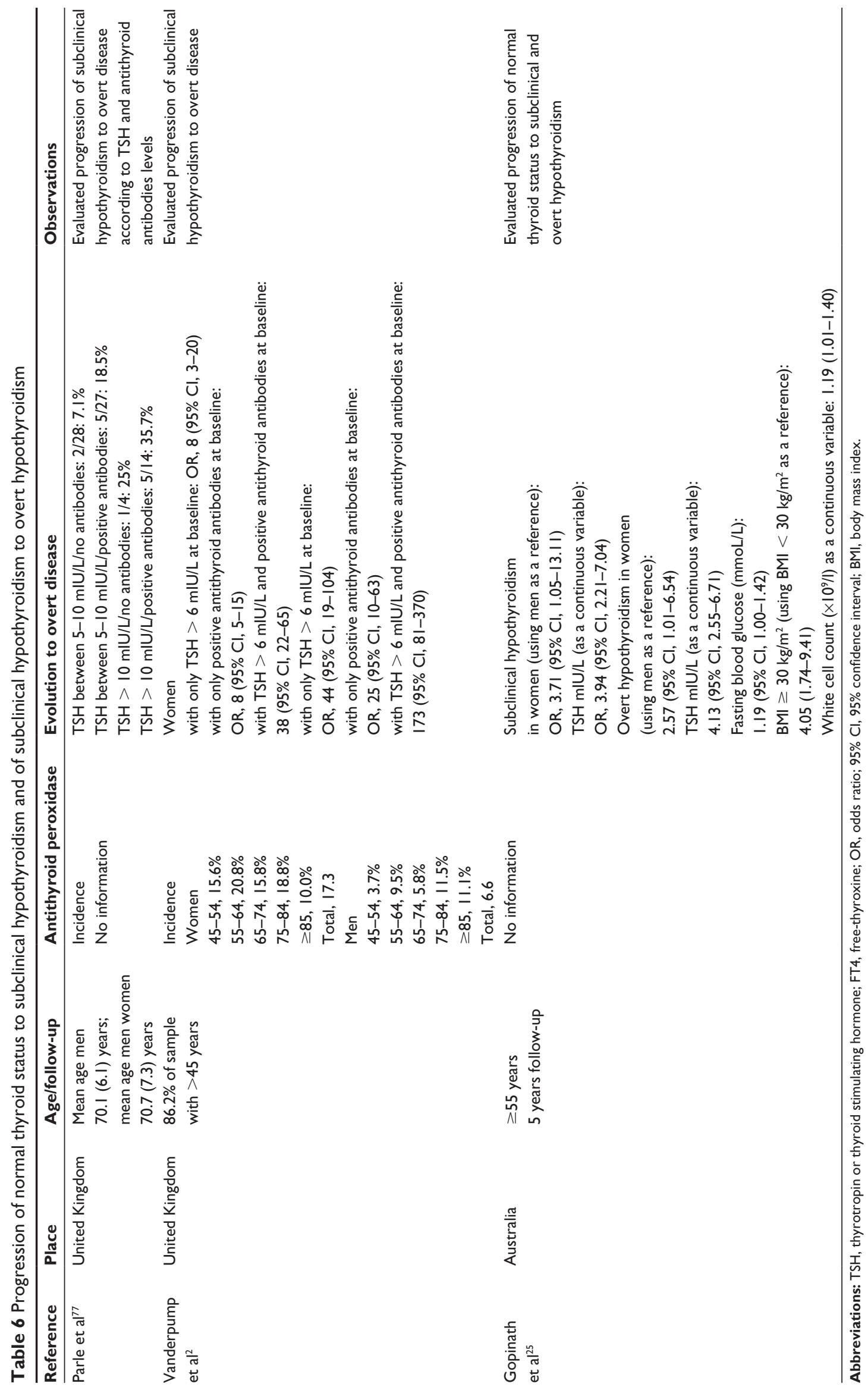




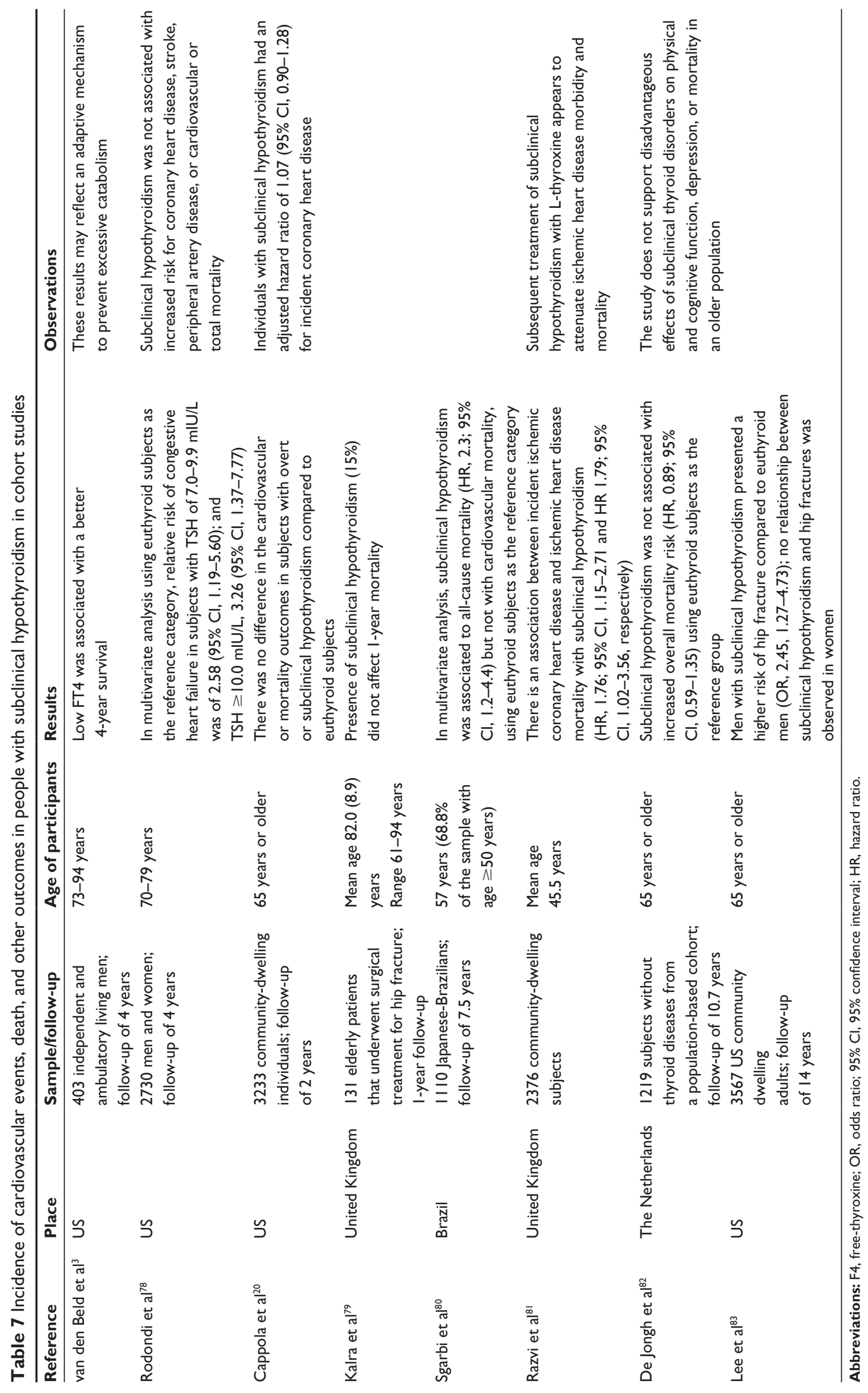


Cardiovascular and all-cause mortality were also elevated in subjects of $<65$ years of age, but not in subjects aged $>65$ years (OR, 1.37; 95\% CI, 1.04-1.79 vs OR, 0.85; 95\% CI, 0.56-1.29) suggesting that increased vascular risk may only be present in subjects with subclinical hypothyroidism who are less than 65 years old. ${ }^{84}$

When subclinical hypothyroidism is treated, an initial L-thyroxine dose of $0.05 \mu \mathrm{g}$ to $0.075 \mu \mathrm{g}$ per day is sufficient to normalize thyroid function. Patients with cardiovascular disease should receive smaller doses of $0.0125 \mu \mathrm{g}$ to $0.025 \mu \mathrm{g}$ per day. Measurements of thyrotropin levels should be repeated 4 to 6 weeks after starting therapy. ${ }^{85}$

\section{Potential bias in the treatment of hypothyroidism regarding age and sex}

Several studies have discussed possible biases in overt hypothyroidism treatment. Gussekloo et al observed 558 participants and found that 39 new cases of overt thyroid disease were not being treated 2 years after diagnosis because the primary care physicians did not start hormone reposition therapy for disorders identified by screening. ${ }^{21}$ These findings suggested the possibility that a diagnosis of hypothyroidism via screening could be a bias in hypothyroidism treatment; age could also be a bias in these cases if this was the real motivation behind the lack of treatment. Interestingly, nothing happened to these untreated patients, possibly suggesting a protective effect of no treatment in overt hypothyroidism since the hazard ratio for mortality for standard deviation increase of $2.71 \mathrm{mIU} / \mathrm{L}$ thyrotropin was 0.77 (95\% CI, 0.63-0.94; $P=0.09$ ). However, as stated by the authors, a well-designed randomized placebo-controlled clinical trial is required to answer this question.

In the two cohorts of the Cardiovascular Health Study (mean age of 73 years; range 65-100 years), Somwaru et al evaluated the use of thyroid hormones along time. Use of thyroid hormones was observed from 1989 to 2006 in the original cohort of 4737 participants, and from 1992 to 2006 in the new cohort of 643 predominantly African-American participants. At the beginning of the study, frequency of hormone use was $8.9 \%$ (95\% CI, 8.1-9.7).${ }^{86}$ However, hormone use increased to $20 \%$ during the 16 years of follow-up, at a rate of approximately $1 \%$ per year. Predictors of the initiation of hormone use during the 16-year follow-up period included being a white woman, being over 85 years old, being more educated, having a higher body mass index, and past history of coronary heart disease. The authors concluded that the differences in thyroid hormone use by sex and race corresponded to the reported demographic differences in TSH distributions, suggesting a minor role of biases in screening practices by sex and race. ${ }^{86}$ These results are similar to those of two other studies. ${ }^{87,88}$

In a sample of 1373 older people living in an economically deprived area, Bensenor et al found more frequent diagnosis of previous overt hypothyroidism in women compared to men $(P=0.006) .{ }^{24}$ The authors speculate that this could be because women seek medical treatment more frequently than men. There could also be some kind of gender bias, since thyroid diseases are more frequent in women compared to men and, consequently, physicians may screen thyroid function with higher frequency in elderly women than men.

Wilson et al reported evidence of an association between socioeconomic deprivation and subclinical thyroid dysfunction. ${ }^{22}$ This association persisted after adjusting for the effects of age, gender, comorbidity, and current drug therapies, and thus could be another source of bias regarding clinical diagnosis of thyroid diseases.

\section{Conclusion}

Subclinical and overt hypothyroidism are common disorders in elderly people, especially women. There is no doubt about the indication for treatment of overt disease; however, the same is not true for subclinical disease. Some data indicates that treatment of subclinical disease results in lipid profile improvement, but there is no evidence that this improvement is associated with a decrease in cardiovascular or all-cause mortality in elderly patients. Close monitoring of thyroid function could be the best option for patients at high risk of progression from subclinical to overt disease.

\section{Disclosure}

The authors report no conflicts of interest in this work.

\section{References}

1. Tunbridge WM, Evered DC, Hall R, et al. The spectrum of thyroid disease in a community: The Whickham Survey. Clin Endocrinol. 1977;7(6):481-493.

2. Vanderpump MP, Tunbridge WM, French JM, et al. The incidence of thyroid disorders in the community: a twenty-year follow-up of the Whickham Survey. Clin Endocrinol. 1995;43(1):55-68.

3. Van den Beld AW, Visser TJ, Feelders RA, Grobbee DE, Lamberts SW. Thyroid hormone concentrations, disease, physical function, and mortality in elderly men. J Clin Endocrinol Metab. 2005;90(12): 6403-6409.

4. Glenn GC. Practice parameter on laboratory panel testing for screening and case finding in asymptomatic adults. Laboratory Testing Task Force of the College of the American Pathologists. Arch Pathol Lab Med. 1996;120(10):929-943.

5. Ladenson PW, Singer PA, Ain KB, et al. American Thyroid Association guidelines for detection of thyroid dysfunction. Arch Intern Med. 2000;160(11):1573-1576. 
6. Klee GG, Hay ID. Biochemical test of thyroid function. Endocrinol Metab Clin North Am. 1997;26(4):763-775.

7. Bjoro T, Homen J, Kruger O, et al. Prevalence of thyroid disease, thyroid dysfunction and thyroid peroxidase antibodies in a large, unselected population. The Health Study of Nord-Trondelag (HUNT). Eur $J$ Endocrinol. 2000;143(5):639-647.

8. Biondi B, Cooper DS. The clinical significance of subclinical thyroid dysfunction. Endocrine Reviews. 2008;29(1):76-131.

9. Andersen S, Pedersen KM, Bruun NH, Laurberg P. Narrow individual variations in serum T(4) and T(3) in normal subjects: a clue to understanding of subclinical thyroid disease. J Clin Endocrinol Metab. 2002;87(3):1068-1072.

10. Hansen PS, Brix TH, Sorensen TI, Kyvik KO, Hegedus L. Major genetic influence on the regulation of the pituitary-thyroid axis: a study of healthy Danish twins. J Clin Endocrinol Metab. 2004;89(3):1181-1187.

11. Hollowell J, Staehling NW, Flanders D, et al. Serum TSH, T4, and thyroid antibodies in the United States population (1988 to 1994): National Health and Nutrition Examination Survey (NHANES III) J Clin Endocrinol Metab. 2002;87(2):489-499.

12. Sawin CT, Castelli WP, Hershman JM, McNamara P, Bacharach P. The aging thyroid. Thyroid deficiency in the Framingham Study. Arch Intern Med. 1985;145(8):1386-1388.

13. Magri F, Muzzoni L, Cravello M, et al. Thyroid function in physiological aging and in Centenarians: possible relationships with some nutritional markers. Metabolism. 2002;51(1):105-109.

14. Mariotti S, Franceschi C, Cossarizza A, Pinchera A. The aging thyroid. Endocr Rev. 1995;16(6):686-715.

15. Mitrou P, Raptis SA, Dimitriadis G. Thyroid disease in older people. Maturitas. 2011;70(1):5-9.

16. Danforth E Jr, Burger AG. The impact of nutrition on thyroid hormone physiology and action. Annu Rev Nutr. 1989;9:201-227.

17. American College of Physicians. Clinical guideline, part 1. Screening for thyroid diseases. Ann Intern Med. 1998;129(2):141-143.

18. American College of Physicians. Clinical guideline, part 2. Screening for thyroid diseases. Ann Intern Med. 1998:129(2):144-158.

19. Flatau E, Trougouboff N, Kaufman N, Reichman N, Luboshitzky R. Prevalence of hypothryroidism and diabetes mellitus in elderly kibbutz members. Eur J Epidemiol. 2000;16(1):43-46.

20. Cappola AR, Fried LP, Arnold AM, et al. Thryroid status, cardiovascular risk, and mortality in older adults. JAMA. 2006;295(9):1033-1041.

21. Gussekloo J, van Exel E, Craen AJ, Meinders AE, Frölich M, Westendorp RG. Thyroid status, disability and cognitive function, and survival in old age. JAMA. 2006;292(21):2591-2599.

22. Wilson S, Parle J, Roberts LM, et al; Birmingham Elderly Thyroid Study Team. Prevalance of subclinical thyroid dysfunction and its relation to socioeconomic deprivation in the elderly: a community-based crosssectional survey. J Clin Endocrinol Metab. 2006;91(12):4809-4816.

23. Diaz-Olmos R, Nogueira AC, Penalva DF, Lotufo PA, Bensenor IM. Frequency of subclinical thyroid dysfunction and risk factors for cardiovascular disease in women at workplace. Sao Paulo Med J. 2010;128(1):18-23.

24. Bensenor I, Goulart AC, Lotufo PA, Menezes PR, Scazufca M. Prevalence of thyroid disorders among older people: results from the São Paulo Ageing and Health Study. Cad Saúde Pública. 2011;27(1):155-161.

25. Gopinath B, Wang JJ, Kifley A, et al. Five-year incidence and progression of thyroid dysfunction in older population. Intern Med J. 2010;40(9):642-649.

26. Patel KV. Epidemiology of anemia in older adults. Semin Hematol. 2008;45(4):210-217.

27. Guralnik JM, Eisenstaedt RS, Ferrucci L, Klein HG, Woodman RC. Prevalence of anemia in persons 65 years and older in the United States: evidence for a high rate of unexplained anemia. Blood. 2004;104(8):2263-2268.

28. Compton WM, Conway KP, Stinson FS, Grant BF. Changes in the prevalence of major depression and comorbid substance use disorders in the United States between 1991-1992 and 2001-2002. Am J Psychiatry. 2006;163(12):2141-2147.
29. Gebretsadik M, Jayaprabhu S, Grossberg GT. Mood disorders in the elderly. Curr Psychiatry Rep. 2006;8(1):34-40.

30. Bensenor I. Screening for thyroid disorders in asymptomatic adults from Brazilian populations. Sao Paulo Med J. 2002;120(5):146-151.

31. Gharib H, Tuttle RM, Baskin HJ, Fish LH, Singer PA, McDermott MT. Consensus Statement \#1: Subclinical thyroid dysfunction: a joint statement on management from the American Association of Clinical Endocrinologists, the American Thyroid Association, and The Endocrine Society. Thyroid. 2005;15(1):24-28.

32. American Association of Clinical Endocrinologists. American Endocrinologists medical guidelines for clinical practice for the evaluation and treatment of hyperthyroidism and hypothyroidism. Endocr Pract. 2002;8(6):457-469.

33. Glenn GC. Practice parameter on laboratory panel testing for screening and case finding in asymptomatic adults. Laboratory Testing Task Force of the College of the American Pathologists. Arch Pathol Lab Med. 1996;120(10):929-943.

34. American Academy of Family Physicians: Summary of Policy Recommendations for Periodic Health Examinations. Leawood, KS: American Academy of Family Physicians; 2002.

35. US Preventive Services Task Force. Screening for thyroid diseases. Available from: http://www.uspreventiveservicestaskforce.org/3rduspstf/ thyroid/thyrrs.htm. Accessed December 28, 2011

36. Canadian Task Force on the Periodic Health Examination. Canadian Guide to Clinical Preventive Health Care. Ottawa, Canada: Canada Communication Group; 1994:611-618.

37. Vanderpump MP, Allquist JA, Franklyn JA, et al. Consensus statement for good practice and audit measures in the management of hypothyroidism and hyperthyroidism. The Research Unit of the Royal College of Physicians of London, the Endocrinology and Diabetes Committee of the Royal College of Physicians of London, and the Society of Endocrinology. BMJ. 1996;313(7056):539-544.

38. Committee on medicare coverage of routine thyroid screening. In: Stone MB, Wallace RB, editors. Medicare Coverage of Routine Screening for Thyroid Dysfunction. Washington, DC: Institute of Medicine; 2003.

39. Surks MI, Ortiz E, Daniels GH, et al. Subclinical thyroid disease: scientific review and guidelines for diagnosis and management. JAMA. 2004;291(2):228-238.

40. Petersen K, Lindstedt G, Lundberg PA, Bengtsson C, Lapidus L, Nyström E. Thyroid disease in middle-aged and elderly Swedish women: thyroid-related hormones, thyroid dysfunction and goiter in relation to age and smoking. Intern Med. 1991;229(5):407-413.

41. Bemben DA, Winn P, Hamm RM, Morgan L, Davis A, Barton E. Thyroid disease in the elderly. Part 1. Prevalence of undiagnosed hypothyroidism. J Fam Practice. 1994;38(6):577-582.

42. Nyström E, Petersen K, Lindstedt G, Lundberg PA. Screening for thyroid disease in women $\geq 50$ years of age seeking hospital care: influence of common nonthyroidal illness on serum free thyroxin as determined by analog radioimmunoassay. Clin Chem. 1988;32(4):603-606.

43. Chen IJ, Hou SK, How CK, et al. Diagnosis of unrecognized primary overt hypothyroidism in the ED. Am J Emerg Med. 2010;28(8): 866-870.

44. Canaris GJ, Steiner JF, Ridgway EC. Do traditional symptoms of hypothyroidism correlate with biochemical disease? J Gen Intern Med. 1997;12(9):544-550.

45. Cooper DS, Halpern R, Wood LC, Levin AA, Ridgway EC. L-Thyroxine therapy in subclinical hypothyroidism. A double-blind placebocontrolled trial. Ann Intern Med. 1984;101(1):18-24.

46. Bemben DA, Hamm RM, Morgan L, Winn P, Davis A, Barton E. Thyroid disease in the elderly. Part 2. Predictability of subclinical hypothyroidism. J Fam Pract. 1994;38(6):583-588.

47. Kong WM, Sheikh MH, Lumb PJ, et al. A 6-month randomized trial of thyroxin treatment in women with mild hypothyroidism. Am J Med. 2002;112(5):348-354

48. Engum A, Bjoro T, Maykletun A, Dahl AA. An association between depression, anxiety and thyroid function - a clinical fact or an artefact? Acta Psychiatr Scand. 2002;106(1):27-34. 
49. Grabe HJ, Volzke H, Ludemann J, et al. Mental and physical complaints in thyroid disorders in the general population. Acta Psychiatr Scand. 2005;112(4):286-293.

50. Jorde R, Waterloo K, Storhaug H, Nyrnes A, Sundsfjord J, Jenssen TG. Neuropsychological function and symptoms in subjects with subclinical hypothyroidism and the effect of thyroxine treatment. J Clin Endocrinol Metab. 2006;91(1):145-153.

51. Zulewski H, Muller B, Exer P, Miserez AR, Staub JJ. Estimation of tissue hypothyroidism by a new clinical score: evaluation of patients with various grades of hypothyroidism and controls. J Clin Endocrinol Metab. 1997;82(3):771-776.

52. Richardson WC, Wilson MC, Keitz SA, Wyer PC; EBM Teaching Scripts Working Group. Tips for teachers of evidence-based medicine: making sense of diagnostic test results using likelihood ratios. $J$ Gen Intern Med. 2008;23(1):87-92.

53. Parle JV, Maisonneuve P, Sheppard MC, Boyle P, Franklyn JA. Prediction of all-cause mortality in elderly people from one low serum thyrotropin results: a 10-year cohort study. Lancet. 2001;358(9285): 861-865.

54. Baskin HJ, Cobin RH, Duick DS, et al. American association of clinical endocrinologists medical guidelines for clinical practice for the evaluation and treatment of hyperthyroidism and hypothyroidism endocrine practice. Endocr Pract. 2002;8(6):457-469.

55. Rosenbaum RL, Barzel US. Levothyroxine replacement dose for primary hypothyroidism decreases with age. Ann Intern Med. 1982;96(1):53-55.

56. Roos A, Linn-Rasker SP, van Domburg R, Tijssen JP, Berghout A. The starting dose of levothyroxine in primary hypothyroidism treatment: a prospective, randomized, double-blind trial. Arch Intern Med. 2005;165(15):1714-1720.

57. Devdhar M, Drooger R, Pehlivanova M, Singh G, Jonklaas J. Levothyroxine replacement doses are affected by gender and weight, but not age. Thyroid. 2011;21(8):821-827.

58. Fazio S, Palmieri EA, Lombardi G, Biondi B. Effects of thyroid hormone on the cardiovascular system. Recent Prog Horm Res. 2004;59:31-50.

59. Clyde PW, Harari AE, Getka EJ, Shakir KM. Combined levothyroxine plus liothyronine compared with levothyroxine alone in primary hypothyroidism: a randomized controlled trial. JAMA. 2003;290(22): 2952-2958

60. Bunevicius R, Kazanavicius G, Zalinkevicius R, Prange AJ Jr. Effects of thyroxine as compared with thyroxine plus triiodothyronine in patients with hypothyroidism. N Engl J Med. 1999;340(6):424-429.

61. Bunevicius R, Jakubonien N, Jurkevicius R, Cernicat J, Lasas L, Prange AJ Jr. Thyroxine vs thyroxine plus triiodothyronine in treatment of hypothyroidism after thyroidectomy for Graves' disease. Endocrine. 2002;18(2):129-133.

62. Siegmund W, Spieker K, Weike AI, et al. Replacement therapy with levothyroxine plus triiodothyronine (bioavailable molar ratio 14:1) is not superior to thyroxine alone to improve well-being and cognitive performance in hypothyroidism. Clin Endocrinol (Oxf). 2004;60(6):750-757.

63. Escobar-Morreale HF, Botella-Carretero JI, Gómez-Bueno M, Galán JM, Barrios V, Sancho J. Thyroid hormone replacement therapy in primary hypothyroidism: a randomized trial comparing L-thyroxine plus liothyronine with L-thyroxine alone. Ann Intern Med. 2005;142(6):412-424.

64. Ma C, Xie J, Huang X, et al. Thyroxine alone or thyroxine plus triiodothyronine replacement therapy for hypothyroidism. Nucl Med Commun. 2009;30(8):586-593.

65. Walsh JP, Shiels L, Limm EM, et al. Combined thyroxine/liothyronine treatment does not improve well-being, quality of life, or cognitive function compared to thyroxine alone: a randomized controlled trial in patients with primary hypothyroidism. $J$ Clin Endocrinol Metab. 2003;88(10):4543-4550.

66. Pollock MA, Sturrock A, Marshall K, et al. Thyroxine treatment in patients with symptoms of hypothyroidism but thyroid function tests within the reference range: randomised double blind placebo controlled crossover trial. BMJ. 2001;323(7318):891-895.
67. Nyström E, Caidahl K, Fager G, Wikkelsö C, Lundberg PA, Lindstedt G. A double-blind crossover 12-month study of L-thyroxine treatment of women with "subclinical" hypothyroidism. Clin Endocrinol (Oxf). 1988;29(1):63-75.

68. Jaeschke R, Guyatt G, Gerstein H, et al. Does treatment with L-thyroxine influence health status in middle-aged and older adults with subclinical hypothyroidism? J Gen Intern Med. 1996;11(12):744-749.

69. Meier C, Staub JJ, Roth CB, et al. TSH-controlled L-thyroxine therapy reduces cholesterol levels and clinical symptoms in subclinical hypothyroidism: a double blind, placebo-controlled trial (Basel Thyroid Study). J Clin Endocrinol Metab. 2001;86(10):4860-4866.

70. Christ-Crain M, Meier C, Guglielmetti M, et al. Elevated C-reactive protein and homocysteine values: cardiovascular risk factors in hypothyroidism? A cross-sectional and a double-blind, placebocontrolled trial. Atherosclerosis. 2003;166(2):379-386.

71. Iqbal A, Jorde R, Figenschau Y. Serum lipid levels in relation to serum thyroid-stimulating hormone and the effect of thyroxine treatment on serum lipid levels in subjects with subclinical hypothyroidism: the Tromsø Study. J Intern Med. 2006;260(1):53-61.

72. Razvi S, Ingoe L, Keeka G, Oates C, McMillan C, Weaver JU. The beneficial effect of L-thyroxine on cardiovascular risk factors, endothelial function, and quality of life in subclinical hypothyroidism: randomized, crossover trial. J Clin Endocrinol Metab. 2007;92(5): $1715-1721$.

73. Teixeira PF, Reuters VS, Ferreira MM, et al. Treatment of subclinical hypothyroidism reduces atherogenic lipid levels in a placebo-controlled double-blind clinical trial. Horm Metab Res. 2008;40(1):50-55.

74. Teixeira Pde F, Reuters VS, Ferreira MM, et al. Lipid profile in different degrees of hypothyroidism and effects of levothyroxine replacement in mild thyroid failure. Transl Res. 2008;151(4):224-231.

75. Nagasaki T, Inaba M, Yamada S, et al. Decrease of brachial-ankle pulse wave velocity in female subclinical hypothyroid patients during normalization of thyroid function: a double-blind placebo-controlled study. Eur J Endocrinol. 2009;160(3):409-415.

76. Parle J, Roberts L, Wilson S, et al. A randomized controlled trial of the effect of thyroxine replacement on cognitive function in community-living elderly subjects with subclinical hypothyroidism: the Birmingham Elderly Thyroid Study. J Clin Endocrinol Metab. 2010;95(8):3623-3632.

77. Parle JV, Franklyn JA, Cross KW, Jones SC, Sheppard MC. Prevalence and follow-up of abnormal thyrotrophin (TSH) concentrations in the elderly in the United Kingdom. Clin Endocrinol (Oxf). 1991;34(1):77-83.

78. Rodondi N, Newman AB, Vittinghoff E, et al. Subclinical hypothyroidism and the risk of heart failure, other cardiovascular events, and death. Arch Intern Med. 2005;165(21):2460-2466.

79. Kalra S, Williams A, Whitaker R, et al. Subclinical thyroid dysfunction does not affect one-year mortality in elderly patients after hip fracture: a prospective longitudinal study. Injury. 2010;41(4):385-387.

80. Sgarbi JA, Matsumura LK, Kasamatsu TS, et al. Subclinical thyroid dysfunctions are independent risk factors for mortality in a 7.5-year follow-up: the Japanese-Brazilian thyroid study. Eur J Endocrinol. 2010;162(3):569-577.

81. Razvi S, Weaver JU, Vanderpump MP, Pearce SH. Heart disease and mortality in people with subclinical hypothyroidism: reanalysis of the Whickham Survey Cohort. J Clin Endocrinol Metab. 2010;95(4): 1734-1740.

82. De Jongh RT, Lips P, Schoor NM, et al. Endogenous subclinical thyroid disorders, physical and cognitive function, depression, and mortality in older individuals. Eur J Endocrinol. 2011;165(4):545-554.

83. Lee JS, Busková P, Fink HA, et al. Subclinical thyroid dysfunction and incident hip fractures in older adults. Arch Intern Med. 2010;170(21): 1876-1883.

84. Razvi S, Shakoor A, Vanderpump M, Weaver JU, Pearce SH. The influence of age on the relationship between subclinical hypothyroidism and ischemic heart disease: a metaanalysis. J Clin Endocrinol Metab. 2008;93(8):2998-3007. 
85. Cooper DS. Subclinical hypothyroidism. N Engl J Med. 2001;345(4): 260-265.

86. Somwaru LL, Arnold AM, Cappola AR. Predictors of thyroid hormone initiation in older adults: results from the cardiovascular health study. J Gerontol A Biol Sci Med Sci. 2011;66(7):809-814.

87. Kanaya AM, Harris F, Volpato S, Perez-Stable EJ, Harris T, Bauer DC. Association between thyroid dysfunction and total cholesterol level in an older biracial population: the health, aging and body composition study. Arch Intern Med. 2002;162(7):773-779.
88. Bauer DC, Rodondi N, Stone KL, Hillier TA. Thyroid hormone use, hyperthyroidism, and mortality in older women. Am J Med. 2007;120(4):343-349.

\section{Publish your work in this journal}

Clinical Interventions in Aging is an international, peer-reviewed journal focusing on evidence-based reports on the value or lack thereof of treatments intended to prevent or delay the onset of maladaptive correlates of aging in human beings. This journal is indexed on PubMed Central, MedLine, the American Chemical Society's 'Chemical Abstracts Ser-

\section{Dovepress}

vice' (CAS), Scopus and the Elsevier Bibliographic databases. The manuscript management system is completely online and includes a very quick and fair peer-review system, which is all easy to use. Visit $\mathrm{http}: / /$ www.dovepress.com/testimonials.php to read real quotes from published authors.

Submit your manuscript here: http://www.dovepress.com/clinical-interventions-in-aging-journal 